\title{
ANALISIS PROSES PEMBELAJARAN MATEMATIKA DI SMK RSBI SURAKARTA
}

\author{
Norma Puspitasari, Imam Sujadi, Suyono
}

\begin{abstract}
This study aims :1)to describe process of learning mathematics in vocational RSBI Surakarta.2) to know whether the process of learning mathematics in vocational RSBI Surakarta whether it is in accordance with quality assurance system RSBI.

This study used a qualitative approach. The subject of this study was a mathematics teacher in class XI program of tourism expertise. The data was taken by RPP and learning activities in the transformation geometry subject. Instruments used observation and interview guide sheet. Techniques of data collection by interview, observation and documentation. The validity of the data used the triangulation methods and data sources. Data analysis techniques included data reduction, data presentation and conclusions.

These results indicated that: 1) The process of learning mathematics at SMK Negeri 6 Surakarta were as follows (a) The planning was not appropriate with the standards process because there are some errors in the writing of the identity, programming skills are not included the amount of meetings and the planning has not been made (b) The implementation of mathematics learning in the transformation geometry subject in early learning activities, the teacher of grade XI mathematics SMK Negeri 6 Surakarta apperception conducted a glimpse for repeating previous material. The main activities of learning, classroom math teacher of SMK Negeri 6 Surakarta XI UPW has implemented major exploration by encouraging students to do the experiment in determining the reflection point and the point of rotation with Geogebra software media, teachers conducted elaboration by discussion and taking conclusion after demonstration done without giving opportunities for students to analyzit. The teacher conducted confirmation by giving positive feedback and reinforcement in verbal to the success of students, gave the confirmation to the result of exploration and elaboration and got correction to the student mistakes. (c) The use of information technology-based media on the powerpoint application program, animation or presentation media in the mathematics learning process was optimally supported by Geogebra media software as supported transformation geometry media. (d) Use the usual methods of teaching applied mathematics teacher SMK Negeri 6 Surakarta was demonstration because it considered suitable for the material submitted with the help of the above media. (e) The use of English in learning mathematics restricted for the opening only, the slides that used in the learning was also not in English. (F) In the end of the lesson the teacher give students chance to ask which part of the material that still not understand, Taking conclusion from the material together with the students, giving exercises, and post test. (g) In the assessment step, grade XI mathematics teacher of SMK Negeri 6 Surakarta correcting students' test results, give feedbacks and comments, restore the work to the students.

The results of the research also showed that; 2) The process of mathematics learning at SMK Negeri 6 Surakarta if it has been related with quality assurance system are (a) The process of mathematics learning is good but not meet the standards process and has not been riched by learning process from one of developed OECD country or other developing country. (b) The process of learning in mathematic have developing a noble character, manners, noble, excellent personality, leadership, life enterpreneural, patriot and soul. (c) The use of English in mathematics teaching was too minimal only at the opening, the delivering materials also have not to use English. (d) The use of ICT have good proved by the learning process using the LCD and Geogebra software.
\end{abstract}

Keywords: Mathematics Learning Process, Vocational RSBI, Quality Assurance System

\section{PENDAHULUAN}

Kemajuan suatu bangsa sangat ditentukan oleh

kualitas sumber daya yang dimiliki, baik sumber

daya alam maupun sumber daya manusia.

Kemajuan akan cepat dicapai bilamana didukung oleh sumber daya alam yang mencukupi dan sumber daya manusia yang berkualitas. Sebaliknya, kemajuan akan terhambat jika faktor sumber daya alam dan/atau sumber daya manusia relatif terbatas. Sumber daya alam merupakan sumber daya pasif, yang 
keberadaannya sangat tergantung pada kualitas sumber daya manusia yang mengelolanya. Apabila sumber daya manusia memiliki kualitas yang unggul, maka sumber daya alam dapat diolah sedemikian rupa sehingga menyumbangkan manfaat dan kontribusi yang besar bagi pembangunan manusia seutuhnya.

Kebijakan renstra nasional mengarahkan untuk menggalakkan sekolah kejuruan sebagai upaya menciptakan manusia Indonesia yang mempunyai skill (pengetahuan, kemampuan dan keterampilan) dalam menghadapi persaingan pasar kerja internasional. Pada tahun 2007 Depdiknas menargetkan perbandingan atau porsi antara Sekolah Menengah Kejuruan (SMK) sebesar 70\% dan Sekolah Menengah Umum (SMA) sebesar 30\%. Dari data statistik nasional menunjukkanbahwa lulusan SMA sebesar 65\%$70 \%$ memilih untuk bekerja, sedangkan sisanya meneruskan ke jenjang pendidikan tinggi. Kondisi lain juga menunjukkan bahwa lulusan SMK lebih siap memasuki pasar kerja dibanding dengan lulusan SMA, disamping itu juga lulusan SMK menjadi salah satu faktor penentu keberhasilan perekonomian di suatu daerah, serta dapat mengurangi pengangguran.

Pemerintah melalui Direktorat Jenderal Manajemen Pendidikan Dasar dan Menengah telah menetapkan tiga rencana strategis dalam jangka menengah, yaitu : (1) peningkatan akses dan pemerataan dalam rangka penuntasan wajib belajar pendidikan dasar;(2) peningkatan mutu, efisiensi, relevansi, dan peningkatan daya saing; dan (3) peningkatan manajemen, akuntabilitas, dan pencitraan publik. Dalam upaya peningkatan mutu, efisiensi, relevansi, dan peningkatan daya saing secara nasional dan sekaligus internasional pada jenjang pendidikan dasar dan menengah, maka telah ditetapkan pentingnya penyelenggaraan pendidikan bertaraf internasional, baik untuk sekolah negeri maupun swasta.

Salah satu upaya dalam peningkatan kemampuan dan pengembangan SDM adalah pembangunan Sekolah Bertaraf Internasional (SBI). Kegiatan atau program SBI adalah penyelenggaraan program pendidikan skala nasional dengan mutu internasional sehingga pendidikan nasional bangsa Indonesia minimal menjadi“tuan rumah" di negeri sendiri. Oleh karena itu dalam menyelenggarakan program SBI dituntut kesiapan semua unsur baik pemerintah pusat, pemerintah daerah(pemerintah provinsi/pemerintah kab/kota) maupun masyarakat, tak terkecuali peran stakeholders (orang tua murid, komite sekolah, warga sekolah, dewan pendidikanserta lembagalembaga yang peduli pada pendidikan).

Berdasarkan amanat Undang - undang No. 20 Tahun 2003 pasal 50 ayat 3 tersebut, Departemen Pendidikan Nasional, Direktorat Jenderal Manajemen Pendidikan Dasar dan Menengah melalui Direktorat Pembinaan Sekolah Menengah Atas / Kejuruan, akan mengembangkan SMA / SMK yang berpotensi untuk melaksanakan proses layanan pendidikan 
berkualitas sehingga menghasilkan lulusan yang memiliki potensi dan prestasi berdaya saing nasional maupun internasional.

Sekolah yang telah ditetapkan sebagai RSBI dalam pelaksanaannya berpedoman pada sepuluh hal yaitu : akreditasi, pengembangan kurikulum KTSP, proses pembelajaran, penilaian, pendidik, tenaga kependidikan, sarana dan prasarana, pengelolaan, pembiayaan dan kesiswaan. Sekolah RSBI bekerja keras melakukan pembenahan di segala bidang untuk menuju SBI. Dalam bidang kurikulum minimal sekolah harus menerapkan Kurikulum Tingkat Satuan Pendidikan (KTSP), memenuhi Standar isi, serta harus berbasis Teknologi Informasi dan Komunikasi (TIK). Sekolah harus mengusahakan muatan pelajaran pada sekolah unggul dari salah satu negara anggota Organization for Economic Cooperation And Development (OECD) dan / atau negara maju lainnya yang mempunyai keunggulan tertentu dalam bidang pendidikan, dan menerapkan standar kelulusan sekolah/madrasah yang lebih tinggi dari Standar Kompetensi Kelulusan.

Dalam bidang proses pembelajaran minimal memenuhi standar proses yaitu pembelajaran disesuaikan dengan bakat, minat, dan perkembangan fisik serta psikologis siswa. Disamping itu, sekolah berusaha meningkatkan proses pembelajaran menjadi teladan bagi sekolah/madrasah lainnya dalam pengembangan akhlak mulia, budi pekerti luhur, kepribadian unggul, kepemimpinan, jiwa entrepreneural, jiwa patriot, dan jiwa inovator.

Proses pembelajaran diperkaya model proses pembelajaran sekolah unggul dari negara anggota OECD dan /atau negara maju lainnya. Menerapkan pembelajaran berbasis TIK, mata pelajaran kelompok sains, matematika, dan inti kejuruan menggunakan bahasa inggris, sementara pembelajaran mata pelajaran lainnya kecuali pelajaran bahasa asing, harus menggunakan bahasa indonesia.

Dalam bidang tenaga pendidik selain memenuhi Standar Pendidik, semua guru mampu memfasilitasi pembelajaran berbasis TIK, guru mata pelajaran kelompok sains, metematika, dan inti kejuruan mampu mengampu pembelajaran berbahasa inggris.

Dalam bidang sarana dan prasarana selain memenuhi standar sarana dan prasarana, ssekolah harus mengusahakan setiap ruang kelas dilengkapi dengan sarana pembelajaran berbasis TIK, perpustakaan dilengkapi dengan sarana digital yang memberikan akses ke sumber pembelajaran berbasis TIK di seluruh dunia, dan sekolah harus dilengkapi dengan ruang multimedia, ruang unjuk seni budaya, fasilitas olahraga, klinik, dan lain sebagainya. Demikian juga pada bidang- bidang yang lain, selain memenuhi Standar Nasional Pendidikan (SNP) masih harus mempunyai nilai lebih.

Proses pembelajaran di sekolah khususnya di RSBI sekarang ini masih belum memuaskan 
karena sebagian besar siswa tidak mampu menghubungkan apa yang mereka pelajari dengan bagaimana pengetahuan tersebut dapat dimanfaatkan untuk memperoleh kecakapan hidup. Akibatnya banyak siswa yang memiliki motivasi rendah dalam mengikuti proses pembelajaran. Kondisi tersebut akan sangat mempengaruhi kualitas pendidikan di Indonesia. Menurut informasi yang dilaporkan Depdiknas tahun 2006, kualitas pendidikan di Indonesia menempati peringkat 109, sedangkan Malaysia menempati urutan 61 dari sejumlah negara di dunia. Berdasarkan fakta itu perlu ada kajian terhadap pelaksanaan kurikulum ( Depdiknas, 2006 ).

Sekolah RSBI berkewajiban menciptakan pembelajaran yang tentu lebih baik. Lebih baik yang dimaksud adalah proses pembelajaran yang tentu saja memenuhi standar proses yang telah ditetapkan pemerintah, diikuti dengan inovasi inovasi yang menyebabkan proses pembelajaran mempunyai keunggulan tersendiri. Namun belum ada jaminan semua guru di SMK RSBI didalam proses pembelajaran sudah memenuhi standar yang ditetapkan oleh pemerintah, bahkan dengan melakukan inovasi-inovasi pembelajaran.

Proses pembelajaran dengan menggunakan bahasa inggris bukanlah hal yang mudah untuk dilaksanakan. Di negara kita bahasa inggris merupakan bahasa asing, yang umumnya masyarakat Indonesia termasuk guru masih rendah kemampuan menggunakan bahasa inggris.

Menerapkan pembelajaran berbasis TIK, apabila digunakan dengan baik dapat menjadi media pembelajaran yang efektif. Salah satu contoh penerapan TIK adalah penggunaan komputer dalam menyampaikan pelajaran. Teknologi komputer dengan kemampuan pembelajarannya yang tinggi dapat dijadikan sebagai sarana penyampaian informasi dan ilmu pengetahuan serta sebagai sarana untuk memperoleh umpan balik bagi siswa. Komputer dapat merangsang siswa untuk mengerjakan latihan, melakukan kegiatan laboratorium atau simulasi karena tersedianya animasi grafik, warna, dan musik yang dapat menambah realisme.

Supaya pembelajaran di kelas menarik dan penuh makna, guru perlu mendesain rencana pembelajaran yang memungkinkan siswa berinteraksi aktif dalam pembelajaran. Begitu pula dalam pembelajaran matematika yang selama ini dianggap sebagai pembelajaran yang sulit dan membosankan. Motivasi serta minat belajar siswa kurang. Padahal pembelajaran matematika mempunyai peranan penting dalam mengembangkan keterampilan dan berpikir logis, sistematis, dan kreatif. Hal ini, karena matematika mempunyai fungsi untuk mengembangkan kemampuan menghitung, mengukur dan menggunakan rumus matematika yang diperlukan dalam kehidupan sehari-hari. Untuk itu kreativitas guru dalam proses 
pembelajaran matematika agar dapat menarik dan tidak membosankan sangat diperlukan.

\section{KAJIAN TEORI}

Sekolah Bertaraf Internasional (SBI) adalah suatu sekolah yang telah memenuhi standar Nasional Pendidikan (SNP) pada tiap aspeknya meliputi kompetensi lulusan, standar isi, standar proses, pendidik dan tenaga kependidikan, sarana dan prasarana, pembiayaan, pengelolaan, dan penilaian serta telah menyelenggarakan dan menghasilkan lulusan dengan ciri keinternasionalannya.

Pemerintah Indonesia melalui Kementerian Pendidikan Nasional mendefinisikan SBI sebagai satuan pendidikan yang diselenggarakan dengan menggunakan Standar Nasional Pendidikan (SNP) dan diperkaya dengan standar salah satu Negara anggota OECD dan atau negara maju lainnya (X), yang dirumuskan :

$$
\mathrm{SNP}+\mathrm{X}
$$

\section{Organisation for Economic Co-Operation and} Development yang selanjutnya disingkat OECD adalah organisasi internasional yang tujuannya membantu pemerintahan negara anggotanya untuk menghadapi tantangan globalisasi ekonomi. Sedangkan negara maju lainnya adalah negara yang tidak termasuk dalam keanggotaan OECD tetapi memiliki keunggulan dalam bidang pendidikan tertentu. (Peraturan Menteri Pendidikan Nasional Republik Indonesia Nomor 78 Tahun 2009 Tentang Penyelenggaraan
Sekolah Bertaraf Internasional Pada Jenjang Pendidikan Dasar Dan Menengah)

Walaupun berbagai peraturan terkait SBI telah diterbitkan, namun belum ada panduan operasional yang jelas untuk mencapai standar tersebut. Dibangunnya faktor ' $\mathrm{X}$ ' oleh masingmasing SBI yang ada di Indonesia mengakibatkan sistem dan model yang dianut oleh masing-masing sekolah jadi berbeda-beda antara yang satu dengan yang lainnya, yang akhirnya berdampak pada kualitas pendidikan dan lulusan yang tidak seragam.

Dengan konsepsi ini, SBI adalah sekolahyang sudah memenuhi dan melaksanakan standar nasional pendidikan yang meliputi: standar isi, standar proses, standar kompetensi lulusan, standar pendidik dan tenaga kependidikan, standar sarana dan prasarana, standar pengelolaan, standar pembiayaan, dan standar penilaian. Selanjutnya aspek-aspek SNP tersebut diperkaya, diperkuat, dikembangkan, diperdalam, diperluas melalui adaptasi atau adopsi standar pendidikan dari salah satu anggota OECD dan/atau negara maju lainnya yang mempunyai keunggulan tertentu dalam bidang pendidikan serta diyakini telah memiliki reputasi mutu yang diakui secara internasional, serta lulusannya memiliki kemampuan daya saing internasional. SBI harus mampu memberikan jaminan bahwa baik dalam penyelenggaraan maupun hasil-hasil pendidikannya lebih tinggi standarnya daripada SNP. Penjaminan ini dapat ditunjukkan kepada 
masyarakat nasional maupun internasional melalui berbagai strategi yang dapat dipertanggungjawabkan.

Pedoman penjaminan mutu sekolah/madrasah bertaraf internasional ini disusun untuk memberikan penjelasan dan ketentuan secara umum bagi para pemangku kepentingan pendidikan di tingkat pusat, provinsi, kabupaten/kota, dan sekolah/madrasah dalam menyelenggarakan sekolah/madrasah bertaraf internasional yang berlandaskan pada peraturan perundang-undangan. Dengan adanya pedoman ini diharapkan seluruh pemangku kepentingan :

1. Memiliki persepsi yang sama tentang penjaminan mutu sekolah/madrasah bertaraf internasional yang efektif, efisien, dan inovatif;

2. Menjabarkan secara operasional sesuai dengan karakteristik dan kebutuhan sekolah/madrasah bertaraf nternasional;dan

3. Melaksanakan seluruh proses penjaminan mutu sekolah/madrasah bertaraf internasional mulai dari kebijakan, perencanaan, pengorganisasian,pelaksanaan, pengkoordinasian, pemantauan, pengevaluasian, dan pelaporannya.

Adapun penjaminan mutu yang berhubungan dengan proses pembelajaran yang diatur dalam pedoman penjaminan mutu adalah mutu setiap sekolah/madrasah bertaraf internasional dijamin dengan keberhasilan melaksanakan proses pembelajaran yang efektif dan efisien. Proses pembelajaran disesuaikan dengan bakat, minat, dan perkembangan fisik serta psikologis siswa. Keberhasilan tersebut ditandai dengan pencapaian indikator kinerja kunci minimal, yaitu memenuhi standar proses.

Selain itu, keberhasilan tersebut juga ditandai dengan pencapaina indikator kinerja kunci tambahan sebagai berikut :

1. Memenuhi standar proses dan standar isi disertai pengembangan dari sekolah unggul salah satu Negara OECD atau Negara maju lainnya.

2. Proses pembelajaran pada satuan mata pelajaran menjadi teladan bagi sekolah/madrasah lainnya dalam pengembangan akhlak mulia, budi pekerti luhur, kepribadian unggul, kepemimpinan, jiwa entrepreneurial, jiwa patriot dan jiwa innovator.

3. Menerapkan pembelajaran berbasis TIK pada semua mata pelajaran.

4. Pembelajaran mata pelajaran kelompok sains, matematika dan inti kejuruan menggunakan bahasa inggris, sementara pembelajaran mata pelajaran yang lainnya, kecuali bahasa asing, harus menggunakan bahasa Indonesia.

Dalam proses pembelajaran selain menggunakan bahasa Indonesia dan bahasa inggris, juga bisa menggunakan bahasa lainnya yang sering 
digunakan dalam forum inernasional, seperti bahasa perancis, spanyol, jepang, arab, dan china.

Proses pembelajaran matematika yang berlangsung di SMK RSBI dinilai berhasil jika pencapaian indicator kinerja kunci minimal terpenuhi, yaitu proses pembelajaran tersebut memenuhi standar proses. Komponen standar proses yang dimaksud adalah sebagai berikut :

\section{1) Perencanaan Pembelajaran}

a) Silabus

Menurut Peratuan Menteri Pendidikan Nasional Indonesia No.41 Tahun 2007(a), silabus merupakan acuan pengembangan RPP. Adapun muatan dari silabus meliputi : identitas mata pelajaran atau tema pelajaran, Standar kompetensi (SK), Kompetensi Dasar (KD), materi pembelajaran,kegiatan pembelajaran, indikator pencapaian kopetensi, penilaian, alokasi waktu dan sumber belajar.

Silabus ini di kembangkan oleh satuan pendidikan berdasarkan :

(1) Standar ISI (SI)

(2) Standar Kompetensi Kelulusan (SKL)

(3) Panduan penyusunan kurikulum Tingkat Satuan Pendidikan (KTSP)

Dalam pelaksanaanya, pengembangan silabus dapat dilakukan oleh para guru secara mandiri atau berkelompok dalam sebuah sekolah/madrasah atau beberapa sekolah, kelompok musyawarah guru mata pelajaran (MGMP).

\section{b) Rencana Pelaksanaan Pembelajaran}

RPP dikembangkan dari silabus dan bertujuan untuk mengarahkan kegiatan belajar siswa dalam upaya mencapai KD. Setiap guru pada satuan pendidikan berkewajiban menyusun RPP secara lengkap dan sistematis agar pembelajaran berlangsung secara interaktif, inspiratif, menyenangkan, menantang, memotivasi siswa untuk berpartisipasi aktif, sertamemberikan ruang yang cukup bagi prakarsa, kreativitas, dan kemandirian sesuai dengan bakat, minat, dan perkembangan fisik serta psikologis siswa

( Peraturan Menteri Pendidikan Nasional RI No.41 Tahun 2007(a)).

RPP disusun untuk setiap KD dan dapat dilaksanakan dalam satu pertemuan atau lebih. Guru merancang penggalan RPP untuk setiap pertemuan yang disesuaikan dengan penjadwalan di satuan pendidikan.

Adapun komponen - komponen RPP berikut penjelasannya berdasarkan Peraturan Menteri Pendidikan Nasional Republik Indonesia No.41 Tahun 2007(a) adalah:

(1) Identitas Mata Pelajaran

Identitas mata pelajaran , meliputi: satuan pendidikan, kelas, semester, program keahlian, mata pelajaran atau tema pelajaran, jumlah pertemuan.

(2) Standar Kompetensi 
Standar Kompetensi merupakan kualifikasi kemampuan minimal siswa yang menggambarkan penguasaan pengetahuan, sikap, dan keterampilan yang diharapkan dicapai pada setiap kelas dan atau semester pada suatu mata pelajaran.

\section{(3) Kompetensi Dasar}

Kompetensi dasar adalah sejumlah kemampuan yang harus dikuasai siswa dalam mata pelajaran tertentu sebagai rujukan penyusunan indikator kompetensi dalam duatu pelajaran.

\section{(4) Indikator Pencapaian Kompetensi}

Indikator pencapaian kompetensi adalah perilaku yang dapat diukur dan atau di observasi untuk menunjukkan ketercapaian kompetesi dasar terntentu yang menjadi acuan penilaian mata pelajaran. Indikator penapaian kompetensi dirumuskan dengan menggunakan kata kerja operasional yang dapat diamati dan diukur, yang mencakup pengetahuan, sikap, dan keterampilan.

\section{(5) Tujuan Pembelajaran}

Tujuan pembelajaran menggambarkan proses dan hasil belajar yang diharapkan dicapai oleh siswa sesuai dengan kompetensi dasar.

(6) Materi ajar

Materi ajar memuat fakta, konsep, prinsip, dan prosesdur yang relevan, dan ditulis dalam bentuk butir - butir sesuai dengan rumusan indikator pencapaian kompetensi.

\section{(7) Alokasi waktu}

Alokasi waktu ditentukan sesuai dengan keperluan untuk pencapain KD dan beban mengajar

(8) Metode Pembelajaran

Metode pembelajaran digunakan oleh guru untuk mewujudkan seuasana belajar dan proses pembelajaran agar peserta didik mencapai kompetensi dasar atau sepenrangkat indikator yang telah ditetapkan. Pemilihan metode pembelajaran disesuaikan dengan situasi dan kondisi siswa, serta karakteristik dari setiap indikator dan kompetensi yang hendak dicapai spada setiap mata pelajaran.

(9) Kegiatan Pembelajaran

(a) Pendahuluan

Pendahuluan merupakan kegiatan awal dalam suatu pertemuan pembelajaran yang di tujukan untuk membangkitkan motivasi dan menfokuskan perhatian siswa untuk berpartisipasi aktif dalam proses pembelajaran.

(b) Inti

Kegiatan inti merupakan proses pembelajaran untuk menacapai KD. Kegiatan pembelajaran dilakukan secara interaktif, inspiratif, menyenangkan, menantang, memotivasi siswa untuk berpartisipasi aktif, serta memberikan ruang yang cukup bagi prakarsa, kreativitas, dan kemndirian sesuai dengan bakat, minat, dan perkembangan 
fisik serta psikologis siswa. Kegiatan inti dilakukan secara sistematis dan sistemik melalui eksplorasi, elaborasi, dan konfirmasi.

(c) Penutup

Penutup merupakan kegiatan yang dilakukan untuk mengakhiri aktivitas pembelajaran yang dapat dilakukan dalam bentuk rangkuman atau kesimpulan, penilaian dan refleksi, umpan balik, dan tindak lanjut.

(10) Penilaian Hasil Belajar

Prosedur dan instrumen penilaian proses hasil belajar disesuaikan dengan indikator pencapaian kompetensi dan mengacu kepada standar penilaian.

\section{(11) Sumber Belajar \\ Penentuan sumber belajar didasarkan} pada standar kompetensi dan kompetensi dasar, serta materi ajar, kegiatan pembelajaran, dan indikator pencapaian kompetensi.

Sebelas komponen RPP ini paling tidak harus senantiasa diikutsertakan dalam setiap pembuatan RPP. Meskipun hakekatnya RPP boleh disusun berdasarkan otoritas dari sekolah yang tetap mengacu pada pedoan yang telah ditetapkan pemerintah dalam hal ini Menteri Pendidikan Nasional Republik Indonesia.

\section{c) Prinsip - prinsip pelaksanaan RPP}

Prinsip - prinsip pelaksanaan RPP berdasarkan Peraturan Menteri Pendidikan
Nasional Republik Indonesia No.41 Tahun 2007(a) berikut penjelasannya:

(1) Memperhatikan perbedaan individu siswa RPP disusun dengan memperhatikan perbedaan jenis kelamin, kemampuan awal, tingkat intelektual, minat, motivasi belajar, bakat, potensi, kemampuan sosial, emosi, gaya belajar, kebutuhan khusus, kecepatatan belajar, latar belakang budaya, norma, nilai, dan / atau lingkungan siswa.

(2) Mendorong partisipasi aktif siswa

Proses pembelajaran dirancang degna berpusat pada siswa untuk mendorong motivasi, minat, kreativitas, inisiatif, inspirasi, kemandirian, dan semangat belajar.

(3) Mengembangkan budaya membaca dan menulis

Proses pembelajaran dirancang untuk mengembangkan kegemaran membaca, pemahaman beragam bacaan, dan berekspresi dalam berbagai bentuk tulisan.

(4) Memberikan umpan balik dan tindak lanjut RPP memuat rancangan program pemberian umpan balik positif, penguatan, pengayaan, dan remidi.

(5) Keterkaitan dan Keterpaduan

RPP disusun dengan memperhatikan keterkaitan dan keterpaduan antara SK,KD,materi pembelajaran, kegiatan pembelajaran, indikator pencapaian komptetensi, penilaian, dan sumber belajar dalam satu 
keutuhan pengalaman belajar. RPP disusun degnan mengakomodasikan pembelajaran tematik, keterpaduan lintas mata pelajaran, lintas aspek belajar, dan keragaman budaya.

(6) Menerapkan teknologi informasi dan komunikasi

RPP disusun dengan memperhitungkan penerapan teknologi informasi dan komunikasi secara terintegrasi, sistematis, dan efektif sesuai dengan situasi dan kondisi.

Prinsip - prinsip penyusunan RPP ini nantinya akan mempermudah guru dalam menyusun RPP. Selain itu guru akan lebih mudah mengembangkan proses pembelajaran yang sesuai dengan pedoman yang telah diajukan pemerintah.

\section{2) Pelaksanaan Proses Pembelajaran}

a) Persyaratan Pelaksanaan Proses

Pembelajaran

Persyaratan pelaksanaan proses

pembelajaran berdasarkan Peraturan

Menteri Pendidikan Nasional Republik

Indonesia No. 41 Tahun 2007 (a).

(1) Rombongan belajar

Jumlah maksimal siswa setiap rombongan belajar adalah:
(a) $\mathrm{SD} / \mathrm{MI} \quad$ :28 siswa
(b) SMP/MT : 32 siswa
(c) SMA/MA : 32 siswa
(d) SMK/MAK : 32 siswa

(2) Beban kerja minimal guru (a) Beban kerja guru mencakup kegiatan pokok yaitu merencanakan pembelajaran, melaksanakan pembelajaran, menilai hasil pembelajaran, membimbing dan melatih siswa, serta melaksanakan tugas tambahan.

(b) Beban kerja guru sebagaimana dimaksud pada huruf a diatas adalah sekurang - kurangnya 24 ( dua puluh empat) jam tatap muka dalam 1 (satu) minggu.

(3) Buku teks pelajaran

(a) Buku teks pelajaran yang akan digunakan oleh sekolah / madrasah dipilih melalui rapat guru dengan pertimbangan komite sekolah / madrasah dari buku buku teks pelajaran yang ditetapkan oleh Menteri.

(b) Rasio buku teks pelajaran untuk peserta didik adalah 1:1 per mata pelajaran

(c) Selain buku teks pelajaran, guru menggunakan buku panduan guru, buku pengayaan, buku referensi dan sumber belajar lainnya.

(d) Guru membiasakan siswa menggunakan buku - buku dan sumber belajar lain yang ada di perpustakaan sekolah / madrasah. 


\section{(4) Pengelolaan kelas}

(e) Guru mengatur tepat duduk sesuai dengan karakteristik siswa dan mata pelajaran, serta aktivitas pembelajaran yang akan dilakukan.

(f) Volume dan intonasi suara guru dalam proses pembelajran harus dapat didengar dengan baik oleh siswa

(g) Tutur kata guru santun dan dapat dimengerti siswa

(h) Guru menyesuaikan materi pelajaran dengan kecepatan dan kemampuan belajar siswa

(i) Guru menciptakan ketertiban, kedisiplinan, kenyamanan, keselamatan, dan kepatuhan pada peraturan dalam menyelenggarakan proses pembelajaran

(j) Guru memberikan penguatan dan umpan balik terhadap respon dan hasil belajar siswa selama proses pembelajaran berlangsung

(k) Guru menghargai siswa tanpa memandang latar belakang agama,suku,jenis kelamin,dan status sosial ekonomi.

(1) Guru menghargai pendapat siswa

(m) Guru memakai pakaian yang sopan,bersih,dan rapi (n) Pada tiap awal semester, guru menyampaikan silabus mata pelajaran yang diampunya.

(o) Guru memulai dan mengakhiri proses pembelajaran sesuai dengan waktu yang dijadwalkan

\section{KERANGKA BERFIKIR}

Pengembangan program Rintisan SMK bertaraf Internasional bertujuan meningkatkan mutu pelayanan dalam menyiapkan lulusan SMK yang memiliki kompetensi lulusan nasional dan mampu berdaya saing pada taraf internasional. Untuk merealisasikan tujuan tersebut sekolah harus mendasarkan pada standar nasional pendidikan dan memperkaya dengan standar pendidikan dari negara maju.

Menghadapi persaingan global, komunikasi memegang peranan penting. Bahasa inggris merupakan bahasa internasional, sumber - sumber belajar dari negara luar menggunakan bahasa inggris. Oleh karena itu, pada pembelajaran di sekolah bertaraf internasional menggunakan bahasa pengantar bahasa inggris. Begitu juga dengan rintisan sekolah bertaraf internasional pembelajaran pada mata pelajaran sains dan matematika diharapkan menggunakan bahasa pengantar bahasa inggris.

Salah satu media berbasis teknologi informasi dan komunikasi adalah komputer, melalui pembelajaran berbasis komputer, bahan ajar dapat disajikan dengan berbagai tampilan atau animasi sehingga kegiatan proses belajar 
mengajar menjadi lebih menarik dan menantang bagi siswa serta mampu meningkatkan motivasi siswa dalam belajar

Proses pembelajaran harus interaktif, inspiratif, menyenangkan, dan menantang sehingga dapat memotivasi siswa untuk berpartisipasi aktif. Guru harus dapat mengembangkan proses pembelajaran yang membangun pengalaman belajar siswa melalui kegiatan pembelajaran yang efektif dan efisien. Guru dituntut untuk memiliki sejumlah pengetahuan dan keterampilan mengelola proses pembelajaran mencakup kemampuan dalam merencanakan, melaksanakan dan mengevaluasi pembelajaran. Kemampuan dalam mengelola proses pembelajaran yang baik akan menunjang efektivitas dan efisiensi pelaksanaan pembelajran sehingga dapat mendukung tercapainya tujuan pembelajaran secara optimal.

Dalam pelaksanaan pembelajaran guru harus dapat menumbuhkan motivasi siswa dalam belajar. Apersepsi dilakukan untuk menarik perhatian siswa, membangkitkan motivasi dan memfokuskan perhatian siswa untuk berpartisipasi aktif dalam proses pembelajaran. Selain itu apersepsi dapat menghubungkan pemahaman siswa antara materi sebelumnya dengan materi yang akan dipelajari, sehingga pemahaman siswa berkesinambungan.

Dari paparan diatas penulis menduga bahwa proses pembelajaran matematika di SMK Negeri 6 Surakarta sudah sesuai dengan sistem penjaminan mutu SMK RSBI namun pelaksanaan dilapangan apakah sudah sesuai dengan sistem penjaminan mutu SMK RSBI atau belum.

\section{METODE PENELITIAN}

Penelitian ini menggunakan pendekatan kualitatif. Subjek penelitian ini adalah guru matematika kelas XI pada program keahlian pariwisata. Data yang diambil adalah RPP dan kegiatan pembelajaran pada materi geometri transformasi. Instrumen yang digunakan adalah lembar observasi dan pedoman wawancara. Teknik pengumpulan data dengan wawancara, observasi dan dokumentasi. Validitas data yang digunakan adalah triangulasi metode dan sumber data. Teknik analisa data meliputi reduksi data, penyajian data dan penarikan kesimpulan.

\section{KESIMPULAN}

Hasil penelitian ini menunjukkan bahwa; SMK Negeri 6 Surakarta adalah sebagai berikut ini: (a) Perencanaan yang dibuat belum sesuai dengan standar proses karena ada beberapa kesalahan dalam penulisan identitas program keahlian, tidak dicantumkan jumlah pertemuan dan perencanaan belum dibuat dalam bentuk bahasa inggris. (b) Pelaksanaan pembelajaran matematika dalam materi Geometri Transformasi yaitu pada kegiatan awal pembelajaran, guru matematika kelas XI SMK Negeri 6 Surakarta melaksanakan kegiatan apersepsi dengan mengulang sekilas materi sebelumnya. Dalam kegiatan inti pembelajaran, 
guru matematika kelas XI SMK Negeri 6 Surakarta jurusan UPW sudah melaksanakan eksplorasi dengan mengajak siswa melakukan percobaan dalam menentukan titik pencerminan dan titik perputaran dengan media software geogebra, guru melakukan elaborasi dengan diskusi dan pengambilan kesimpulan setelah demonstrasi dilakukan, belum memberikan kesempatan kepada siswa untuk menganalisis. Guru melakukan konfirmasi dengan memberikan umpan balik positif dan penguatan dalam bentuk lisan terhadap keberhasilan siswa, memberikan konfirmasi terhadap hasil eksplorasi dan elaborasi dan melakukan koreksi atas kesalahan siswa. (c) Penggunaan media berbasis teknologi informasi pada program aplikasi powerpoint, animasi atau media presentasi dalam proses pembelajaran matematika sudah optimal didukung dengan software geogebra sebagai media bantu materi geometri transformasi. (d)Penggunaan metode pembelajaran yang biasa diterapkan guru matematika SMK Negeri 6 Surakarta adalah demonstrasi karena dianggap cocok bagi materi yang disampaikan dengan bantuan media tersebut diatas. (e) Penggunaan bahasa inggris dalam pembelajaran sebatas pada pembukaan saja, slide yang digunakan dalam pembelajaran juga belum dalam bahasa inggris. (f) Dalam mengakhiri pelajaran yang dilakukan oleh guru adalah memberikan kesempatan kepada siswa untuk bertanya bagian yang masih belum dipahami, bersama-sama dengan siswa membuat kesimpulan dari materi yang dipelajari, memberikan latihan soal, dan memberikan post test.

(g) Dalam tahapan penilaian, guru matematika kelas XI SMK Negeri 6 Surakarta mengoreksi hasil siswa, memberikan tanggapan dan komentar, mengembalikan hasil pekerjaan kepada siswa.

Hasil penelitian juga menunjukkan bahwa; 2) Proses pembelajaran matematika di SMK Negeri 6 Surakarta jika dikaitkan dengan system penjaminan mutu maka (a) Proses pembelajaran matematika sudah baik namun belum memenuhi standar proses dan belum diperkaya dengan proses pembelajaran dari salah satu negara OECD atau negara maju lainya. (b) Proses pembelajaran pada mata pelajaran matematika sudah mengembangkan akhlak mulia, budi pekerti luhur, kepribadian unggul, kepemimpinan, jiwa enterpreneural, jiwa patriot, dan jiwa innovator namun belum tersirat pada RPP. (c) Penggunaan bahasa inggris dalam pembelajaran matematika sangat minim sekali hanya pada pembukaan, penyampain materi juga belum menggunakan bahasa inggris.(d) Penggunaan TIK sudah baik dibuktikan dengan proses pembelajaran dengan menggunakan LCD dan software geogebra.

\section{SARAN}

Berdasarkan hasil penelitian, untuk dapat memberikan manfaat yang sebesar-besarnya, untuk dapat ditindak lanjuti sehingga kedepannya pelaksanaan pembelajaran matematika di SMK RSBI dapat lebih 
ditingkatkan lagi, dan memberikan hasil yang lebih optimal.

1. Kepala sekolah

a. Kepala sekolah melakukan observasi terhadap pembelajaran guru di kelas sehingga dapat mengetahui seberapa jauh guru sudah melaksanakan pembelajaran sesuai dengan standar proses pendidikan dan pedoman penyelenggaraan SMK RSBI

b. Kepala sekolah senantiasa memberikan motivasi kepada guru untuk meningkatkan pengetahuannya, beasiswa yang diberikan kepada guru untuk melanjutkan studi ditingkatkan sehingga meningkatkan motivasi untuk dapat berubah menyesuaikan diri dengan perkembangan pengetahuan

c. Kepala sekolah dapat mengoptimalkan pembelajaran berbasis teknologi informasi dengan melengkapi fasilitas komputer dan jaringan internet yang diperluas.

\section{Guru}

a. Selalu memotivasi diri sendiri untuk menyesuaikan diri dengan kemajuan teknologi dalam pengembangan pembelajaran

\section{DAFTAR PUSTAKA}

$\begin{array}{ccc}\text { Departemen } & \text { Pendidikan Nasional. } & 2007 . \\ \text { "Pedoman } & \text { Penjaminan } & \text { Mutu }\end{array}$

b. Mengembangkan kreativitas dan menyusun media pembelajaran yang disesuaikan dengan kebutuhan kondisi siswa, dan masing - masing kompetensi dasar yang akan diajarkan.

c. Meningkatkan kualitas profesi dengan melanjutkan studi ke jenjang yang lebih tinggi guna meningkatkan profesionalisme pekerjaan

d. Meningkatkan kemampuan berbahasa inggris guna menyesuaikan dengan kurikulum RSBI yang berlaku.

3. Siswa

a. Selalu memotivasi diri untuk belajar bukan hanya dari guru tetapi juga dari sarana lain. Misalnya, membaca buku diperpustakaan, surat kabar, majalah, media informasi seperti radio, televisi dan internet

b. Menggunakan kesempatan untuk bertanya kepada guru di dalam kelas agar memperoleh informasi sebanyak banyaknya.

c. Aktif berdiskusi dengan teman dan menggunakan waktu luang untuk belajar.

Sekolah/Madrasah Bertaraf Internasional pada Jenjang Pendidikan Dasar dan Menengah”. Jakarta: Depdiknas. 
Depdiknas. 2006(a). Sistem Penyelenggaraan Sekolah Bertaraf Internasional Untuk Pendidikan Dasar dan Menengah. Jakarta.

Depdiknas. 2006(b). Peraturan Menteri Pendidikan Nasional Republik Indonesia No. 23 Tahun 2006 tentang Standar Kompetensi Kelulusan. Jakarta.

Depdiknas. 2007(a). Peraturan Menteri Pendidikan Nasional Republik Indonesia No. 41 tahun 2009 tentang Standar Proses untuk satuan Pendidikan Dasar dan Menengah. Jakarta.

Depdiknas. 2007(b). Peraturan Menteri

Pendidikan Nasional Republik Indonesia No. 78 tahun 2009 tentang Penyelenggaraan
Sekolah Bertaraf Internasional pada Jenjang Pendidikan Dasar dan Menengah. Jakarta. Depdiknas. 2009. Pedoman Penjaminan Mutu Sekolah/madrasah Bertaraf Internasional pada Jenjang Pendidikan Dasar dan Menengah. Jakarta.

Lexy J. Moleong. 2008. Metodologi Penelitian Kualitatif. Bandung: PT. Remaja Rosdakarya.

Zainal Arifin. 2011. Evaluasi Pembelajaran. Bandung : Rosdakarya

Zainal Aqib. 2010. Membangun Prestise Sekolah Standar Nasional SSN dan SBI Sekolah Berstandar Internasional. Bandung : Yrama Widya 